\title{
Hepatitis C virus fails to activate NF-kappaB signaling in plasmacytoid dendritic cells
}

\author{
Ruzena Stranska*, Jonathan Florentin, Clélia Dental, Besma Aouar, Francoise Gondois-Rey, David Durantel, \\ Thomas F Baumert, Jacques A Nunes, Daniel Olive, Ivan Hirsch \\ From 17th International Symposium on HIV and Emerging Infectious Diseases (ISHEID) \\ Marseille, France. 23-25 May 2012
}

\section{Introduction}

Plasmacytoid dendritic cells (pDCs) respond to viral infection by production of interferon $\alpha$ (IFN- $\alpha$ ), proinflammatory cytokines and cell differentiation. The elimination of hepatitis $\mathrm{C}$ virus $(\mathrm{HCV})$ in more than $50 \%$ of chronically infected patients by treatment with IFN- $\alpha$ suggests that pDCs can play an important role in the control of $\mathrm{HCV}$ infection. pDCs exposed to HCV-infected hepatoma cells, in contrast to cell-free $\mathrm{HCV}$ virions, produce large amounts of IFN- $\alpha$.

\section{Materials and methods}

To further investigate the molecular mechanism of $\mathrm{HCV}$ sensing, we studied whether exposure of pDCs to HCVinfected hepatoma cells activates in parallel to interferon regulatory factor 7 (IRF7)-mediated production of IFN- $\alpha$ also nuclear factor kappa B (NF- $\kappa \mathrm{B})$-dependent pDC responses such as expression of the differentiation markers CD40, CCR7, CD86, and tumor necrosis factor (TNF)related apoptosis-inducing ligand (TRAIL), and secretion of the proinflammatory cytokines TNF- $\alpha$ and interleukin 6 (IL-6).

\section{RESULTS}

We demonstrate that exposure of pDCs to HCV-infected hepatoma cells surprisingly did not induce phosphorylation of NF- $\kappa \mathrm{B}$ or cell surface expression of CD40, CCR7, CD86, and TRAIL, or secretion of TNF- $\alpha$ and IL-6. In contrast, CpG-A and CpG-B induced production of TNF$\alpha$ and IL- 6 in pDCs exposed to the HCV-infected hepatoma cells, showing that cell-associated virus did not actively inhibit toll-like receptor (TLR)-mediated NF- $\kappa \mathrm{B}$ phosphorylation.

\footnotetext{
* Correspondence: ruzena.stranska@inserm.fr

Centre de Recherche en Cancérologie de Marseille, Marseille, France
}

\section{Conclusions}

Our results suggest that cell associated HCV signals in pDCs via endocytosis-dependent mechanism and IRF7 but not via NF- $\kappa$ B pathway. In spite of IFN- $\alpha$ induction, cell-associated $\mathrm{HCV}$ does not induce a full functional response of pDCs. These findings contribute to the understanding of evasion of immune responses by HCV.

Published: 25 May 2012

doi:10.1186/1742-4690-9-S1-05

Cite this article as: Stranska et al:: Hepatitis C virus fails to activate NFkappaB signaling in plasmacytoid dendritic cells. Retrovirology 20129 (Suppl 1):05.
Submit your next manuscript to BioMed Central and take full advantage of:

- Convenient online submission

- Thorough peer review

- No space constraints or color figure charges

- Immediate publication on acceptance

- Inclusion in PubMed, CAS, Scopus and Google Scholar

- Research which is freely available for redistribution

Submit your manuscript at www.biomedcentral.com/submit
() Biomed Central 